\title{
Fruit Market in the City of Lavras, Minas Gerais, Brazil from 2004 to 2017
}

\author{
José Clélio de Andrade, Lair Victor Pereira, Ângelo Albérico Alvarenga, Ester Alice Ferreira, \\ Paulo Márcio Norberto, Marcelo Ribeiro Malta
}

Searchers for the Agricultural Research Company of Minas Gerais, EPAMIG, Lavras, Brazil

Email: jclelio@epamig.br

How to cite this paper: de Andrade, J.C., Pereira, L.V., Alvarenga, Â.A., Ferreira, E.A., Norberto, P.M. and Malta, M.R. (2017) Fruit Market in the City of Lavras, Minas Gerais, Brazil from 2004 to 2017. Agricultural Sciences, 8, 1278-1282. https://doi.org/10.4236/as.2017.811092

Received: June 10, 2017

Accepted: November 14, 2017

Published: November 17, 2017

Copyright $\odot 2017$ by authors and Scientific Research Publishing Inc. This work is licensed under the Creative Commons Attribution International License (CC BY 4.0).

http://creativecommons.org/licenses/by/4.0/

\begin{abstract}
Fruit growing has achieved advances through the use of new technologies generated by research. In Brazil, it is one of the most prominent sectors in agribusiness, achieving significant results and generating business opportunities. In this way, the fruit market has grown considerably in the last decades, both in quantity and in quality. Allied to this, the changes in consumer behavior regarding food consumption have been responsible for the increase of the fruit market. The objective of this work was to know the evolution of the fruit trade in the city of Lavras, state of Minas Gerais, Brazil, in relation to the quantity sold, monetary value, losses in the gondolas of retail establishments and per capita consumption of the population of this city.
\end{abstract}

\section{Keywords}

Market, Fruits, Consumption

\section{Introduction}

One of the most important sectors in the world agribusiness is fruit growing, which includes a large number of fruit trees. Brazil with a great territorial extension, allied to the climatic diversity, allows the production of the most diverse fruits, generating great opportunities for the agribusiness. Taking advantage of this advantage, the country produced 38.36 million tons of fruit in 2013, placing it in the 3rd place in the world ranking, surpassed only by China and India, which produced 137.6 and 71.07 million tons of fruit, in that same period [1].

Fruit farming, besides having economic importance, generates a great number of jobs, distributing wealth in all layers of society. According to the IBRAF [2], fruit growing in Brazil occupied an area of 2.2 million hectares, moved US\$ 5.29 billion and employed 5.6 million people, representing $27 \%$ of the agricultural 
labor force from the country.

The fruit market has grown considerably in the last decades, both in quantity and in quality. This was possible because of advances in research and development in the industry. In four decades, Brazil has passed from importer to exporter of some temperate fruits, such as apple. In the 1970s, the national production of this fruit represented only $10 \%$ of domestic consumption. Today, there are more than 36,000 hectares producing high quality apples, enough to meet the domestic market and even for export [3] [4].

The changes in consumer behavior, with regard to food consumption, have been responsible for the increase in the fruit market [5]. Faced with this trend, the Center for Advanced Studies in Applied Economics, University of São Paulo (CEPEA-USP), conducted a survey on fruit consumption in Brazil, which showed an average increase of approximately $4.38 \mathrm{~kg}$ per person per year, from 2005 to 2011 [6].

The objective of this work was to know the fruit market of the city of Lavras, MG, Brazil, from 2004 to 2017, in relation to the volume sold, monetary value, percentage of losses in gondolas and per capita consumption of fruits of the population.

\section{Methodology}

This research was carried out in three stages in the city of Lavras, MG, Brazil, the first one in the months of August to January of 2004/2005; the second in the months of August to January 2011/2012, and the third in the months of August to January 2016/2017, in the various supermarket chains, sweatshops and free markets.

The data collection was performed monthly, through a spreadsheet with questions about quantity marketed, total value of consumer prices and percentage of losses in gondolas. The data collected were tabulated and analyzed monthly.

The sampling of the number of establishments interviewed was carried out according to the criteria of Cochran [7], in which locality with more than fifty commercial establishments of fruit the sample is of $10 \%$, of ten to forty of $20 \%$ and with less than ten of $100 \%$. For this research carried out in the city of Lavras, Minas Gerais, Brazil, the sample was $100 \%$ of the four networks of supermarket establishments and ten retail establishments.

\section{Results and Discussion}

According to the data presented in Table 1, it can be seen that, in the first stage (2004/2005), an average of $377.6 \mathrm{t}$ of fruits per month was traded, moving around US $\$ 18,850,798$, with a price average of US $\$ 0.50$ per $\mathrm{kg}$ of fruit.

In the second phase (2011/2012), there were $650.8 \mathrm{t}$ of fruits per month, moving US\$396.808.30 monthly, with an average price of US\$ 0.61 per kilo [3].

Finally, in the third stage, this average rose to $786.3 \mathrm{t}$ monthly, moving US\$ 60,995,207 per month at an average price of US\$ 0.79 per kg of fruit. In a 
Table 1. Quantity ( $\mathrm{t}$ ) and value (US\$) of the fruit marketed in Lavras from August to January 2004/2005, 2011/2012 and 2016/2017.

\begin{tabular}{ccccccc}
\hline & \multicolumn{6}{c}{ Stages } \\
\cline { 2 - 7 } $\begin{array}{c}\text { Month/ } \\
\text { Stages }\end{array}$ & \multicolumn{2}{c}{$2004 / 2005$} & \multicolumn{2}{c}{$2011 / 2012$} & \multicolumn{2}{c}{$2016 / 2017$} \\
\cline { 2 - 7 } & $\begin{array}{c}\text { Amount } \\
(\mathrm{t})\end{array}$ & $\begin{array}{c}\text { value } \\
(\mathrm{US} \$ 1,000.00)\end{array}$ & $\begin{array}{c}\text { Amount } \\
(\mathrm{t})\end{array}$ & $\begin{array}{c}\text { value } \\
(\mathrm{US} \$ 1,000.00)\end{array}$ & $\begin{array}{c}\text { Amount } \\
(\mathrm{t})\end{array}$ & $\begin{array}{c}\text { value } \\
(\text { US } \$ 1,000.00)\end{array}$ \\
\hline August & 385.9 & 185.75 & 642.6 & 402.36 & 783.3 & 605.61 \\
September & 383.0 & 188.78 & 634.9 & 391.46 & 822.0 & 635.53 \\
October & 350.9 & 169.65 & 589.1 & 365.11 & 851.3 & 658.19 \\
November & 355.0 & 193.80 & 591.1 & 366.19 & 798.4 & 617.29 \\
December & 401.1 & 199.84 & 667.7 & 443.70 & 874.0 & 675.74 \\
January & 389.7 & 197.60 & 644.8 & 412.01 & 824.6 & 637.54 \\
Average & 377.6 & 189.14 & 650.8 & 396.80 & 825.6 & 638.32 \\
\hline
\end{tabular}

${ }^{\star}$ Dollar quotation on September 20, 2017 (US\$ $\left.1.00=\mathrm{R} \$ 3.13\right)$.

study conducted by Andrade et al. [8] in the period of 2014/2015, similar results were observed.

According to the data presented, evolution of $72.35 \%$ from the first to the second stage and $108.23 \%$ from the first to the third stage is observed, clearly showing the trend of increase in fruit consumption by the population, mainly motivated health aspects and the search for a better quality of life.

In six years, from the first to the second stage, per capita fruit consumption in Lavras rose from $47.76 \mathrm{~kg} /$ inhabitant/year to $58.90 \mathrm{~kg} /$ inhabitant/year [3]. In that interval, consumption per capita had an increase of $11.14 \mathrm{~kg}$ per person per year, which was more than double the average in Brazil, where there was an increase of $4.38 \mathrm{~kg}$ per person per year [6].

Comparing the evolution from the first one (2004/2005) to the third stage (2016/2017), per capita consumption increased from $47.76 \mathrm{~kg} /$ inhabitant/year [4] to $78.63 \mathrm{~kg} /$ inhabitant/year, representing an increase of $30.87 \mathrm{~kg} / \mathrm{hab} /$ year, a $64.63 \%$ increase in per capita consumption.

The per capita consumption in 2010 in Brazil was $57.00 \mathrm{~kg} / \mathrm{hab} / \mathrm{year}$, in Italy, 114.00 and in Spain, $120.00 \mathrm{~kg} / \mathrm{hab} /$ year, according to FAO [1]. In Lavras, although per capita consumption is above the national average, it is still below that in Italy and Spain [3]. This fact can be explained by the increase in the supply of fruit in the retail market, as a consequence of the increase in the demand for the population, due to the behavioral changes of the population that started to look for healthier foods, together with an improvement of the purchasing power of the society in general, as well as the improvement of the supply and distribution of these products by the retail network with assiduity and punctuality.

The losses of the fruits in the supermarket shelves and bakeries went from $7.8 \%$ [3], in the first stage, to $4.6 \%$ in the third stage, as reported by those responsible for the hortifrúti section of the establishments surveyed. There was a 
Table 2. Most traded fruit (t) in Lavras, MG, from August 2016 to January 2017.

\begin{tabular}{cccccccc}
\hline Fruits/month & Ago/16 & Set/16 & Out/16 & Nov/16 & Dez/16 & Jan/17 & Average \\
\hline Banana Prata & 92.79 & 109.66 & 109.93 & 102.24 & 104.72 & 94.38 & 102.29 \\
Banana Nanica & 28.29 & 27.09 & 33.30 & 40.79 & 47.85 & 53.46 & 37.13 \\
Orange Pêra & 105.85 & 109.66 & 121.90 & 107.99 & 102.13 & 104.60 & 108.68 \\
National apple & 44.52 & 41.29 & 56.05 & 38.87 & 69.30 & 45.44 & 49.24 \\
Papaya Formosa & 19.50 & 24.29 & 19.37 & 20.86 & 18.73 & 21.50 & 20.70 \\
Papaya Amazonas & 15.01 & 18.70 & 16.37 & 20.15 & 21.14 & 22.34 & 18.95 \\
Pineapple Pérola & 20.86 & 18.92 & 18.72 & 24.01 & 30.60 & 18.29 & 21.23 \\
Grape Rosada & - & - & - & - & 37.74 & - & - \\
Mango Palmer & - & - & - & - & - & 35.72 & - \\
Sub-total & 326.82 & 349.58 & 375.64 & 354.91 & 432.21 & 395.73 & 358.22 \\
Others & 456.78 & 472.42 & 475.66 & 433.49 & 441.79 & 428.87 & 467.38 \\
TOTAL & 783.30 & 822.00 & 851.30 & 798.40 & 874.00 & 824.60 & 825.60 \\
\hline
\end{tabular}

*Subtotal for banana, orange, apple, papaya and pineapple.

reduction in losses from 64.24 to $40.48 \mathrm{t} /$ month, that is, $23.76 \mathrm{t} /$ month less, representing a saving in waste of US\$18,294.40 per month. This is due to the efforts made by the management of Ceasa Minas in the logistics of distribution to the final consumer.

Table 2 shows the data of the main fruits commercialized in the city of Lavras, MG, in the third stage of this research, from August 2016 to January 2017. The banana was the most commercialized fruit, with a monthly average of $139.42 \mathrm{t}$, of which the cultivar Prata contributes with 102.29 t, the "Nanica", with $37.13 \mathrm{t}$. The second most traded fruit was the "Pêra" orange, with a monthly average of $108.68 \mathrm{t}$, followed by the national apple, with $49.24 \mathrm{t}$, and papaya with $39.65 \mathrm{t}$, with $20.70 \mathrm{t}$ of papaya "Formosa", and $18.95 \mathrm{t}$ of the "Amazonas" papaya. In December 2016, the "Rosada" grape was the 5th placed with $37.74 \mathrm{t}$ and in January 2017 this position was occupied by the "Palmer" mango, with $35.72 \mathrm{t}$.

In the three steps studied, it is verified that the month of December was the month of greatest fruit supply in the city of Lavras. It can be said that this event is due to the greater supply of fruit, accompanied by the greater demand for the population, a factor motivated by the Christmas festivities and also by the increase of income, with the receipt of the $13^{\text {th }}$ salary.

As for the increase in the volume of fruit traded, it can be said that it is a consequence of the increase of productivity and quality, as well as the constant supply of these products during all months of the year. This offer, in turn, is provided by the technological development coming from the results of continuous scientific research, which has made possible the advancement of fruit growing in the various geographic regions of Brazil. 


\section{Conclusions}

The commercialization, consumption and supply of fruit with quality, attendance and punctuality in Lavras have increased.

Losses in facilities have decreased as a result of more efficient distribution logistics.

Technological development has provided better quality fruit during all months of the year, favoring increased consumption, which has also been driven by the change in consumer habits.

\section{References}

[1] (2015) AGRONEGÓCIO: Fruticultura: Boletim de Inteligência. http://www.bibliotecas.sebrae.com.br/chronus/ARQUIVOS_CHRONUS/bds/bds.ns f/64ab878c176e5103877bfd3f92a2a68f/\$File/5791.pdf

[2] Andrade, J.C., Pereira, L.V., Abrahão, E., Alvarenga, A.A. and Malta, M.R. (2012) Mercado de frutas em Lavras-MG. EPAMIG-CTSM, Lavras, 3 p. (EPAMIG-CTSM. Circular Técnica, 149).

[3] Andrade, J.C., Pereira, L.V., Alvarenga, A.A., Malta, M.R. and Mendes, J.M.C. (2012) Performance do comercio de frutas em Lavras-MG, nos períodos de 2004/2005 a 2011/2012. In: Congresso Brasileiro de Fruticultura, Sociedade Brasileira de Fruticultura, Bento Gonçalves, 2606-2610.

[4] Cochran, W.G. (1965) The Planning of Observational Studies of Human Populations. Journal of the Royal Statistical Society, Series A (General), 128, 234-266. https://doi.org/10.2307/2344179

[5] Instituto Brasileiro de Frutas-IBRAF (2010) Produção Brasileira de Frutas, 2009. http://www.ibraf.org.br/estatisticas/ProduçãoBrasileira de Frutas 2009-Final.pdf

[6] Pimentel, P.M. and Pimentel, L.P. (2011) Tendências do mercado de frutas de uso imediato. Embrapa Clima Temperado, Pelotas. http://www.ceinfo.cnpct.embrapa/artigo_contexto.plep?op=1\&

[7] Silveira, J., Galeskas, H., Tapetti, R. and Lourencini, I. (2011) Quem é o consumidor brasileiro de frutas e hortaliças? Hortifruti Brasil, Piracicaba, 103, 8-23.

http://www.hfbrasil.org.br/br/revista/acessar/quem-e-o-consumidor-brasileiro-de-f rutas-e-hortalicas.aspx

[8] Andrade, J.C., Pereira, L.V., Alvarenga, A.A., Ferreira, E.A. and Norberto, P.M. (2017) Evolution of the Fruit Market in the City of Lavras-Minas Gerais-Brazil. International Journal of Environmental \& Agriculture Research, 3, 32-36. 